\title{
Undergraduate Certificate in Swine Production Management
}

\section{DOI:10.31274/air.13021}

Jennifer M. Bundy, Assistant Professor; Elisabeth Huff-Lonergan, Professor; Jodi A. Sterle, Professor; Joan E. Cunnick, Professor;

Christen G. Burgett, Associate Teaching Professor; Laura L. Greiner, Assistant Professor; Elizabeth A. Bobeck, Assistant Professor; Nicholas K. Gabler, Professor; Steven M. Lonergan, Morrill Professor; Department of Animal Science, Iowa State University

\section{Summary and Implications}

Iowa State University (ISU) offers undergraduate certificates to demonstrate completion of a focused study in a specialized area across a variety of disciplines. The certificate has the significant benefit of allowing students to customize their curriculum and document an approved course of study. A Swine Production Management Certificate is now offered within the Animal Science Department at ISU. The certificate requirements are organized to correspond with faculty and employer-defined needs for a successful transition from ISU student to swine industry professional.

The Swine Production Management certificate will integrate technical topics in animal science with practical considerations in enterprise management. Two critical components to the certificate are the capstone Swine Systems Management course and a required internship with a focus on swine production management. Students that complete the certificate will have the background to identify and address challenges in modern swine production enterprises. Further, the certificate assists employers in identifying students that have shown the interest, discipline, and ability to complete this specialized study program.

\section{Introduction}

The swine industry is part of the Iowa, U.S., and global economy. The United States pork industry will produce nearly 13,000,000 metric tons and export 3,000,000 metric tons of pork this year. The Iowa swine industry produces almost one-third of the nation's pigs and is a crucial part of a critical U.S. and global industry. An industry of this size and requires a workforce with technical competency to manage swine production, nutrition, genetics, health programs, biosecurity, welfare, and facilities. The demand for professionals with expertise in swine production management is rapidly growing, especially in the state of Iowa. Over 147,000 jobs in Iowa were associated with the Iowa pork industry in 2019. Expertise is necessary for traditional production venues and is also expanding to environmental quality, food safety, and sustainability. Students need a clear path to customize and document their training and expertise in this swine production management. Documentation of the certificate on the transcript provides a way for students to show how they pursued and completed a customized course of study and have achieved competency in swine production management.

\section{Approach}

The objective was to develop a swine production management course of study within the requirements of an undergraduate certificate. Students that complete the certificate will be able to:

a. Demonstrate a breadth of understanding of nutrition, physiology, and breeding applications in contemporary swine production systems.

b. Evaluate production systems and provide solutions to ensure the efficient production of safe, high-quality pork.

c. Recognize challenges to environmental sustainability and be aware of environmental considerations in swine production systems.

d. Demonstrate competence in hands-on and practical applications in their field.

e. Integrate technical knowledge with enterprise management to ensure profitable and sustainable management of swine production. Demonstrate the development of the knowledge, skills, and abilities necessary for a swine production management career.

\section{Requirements of the Swine Production Management Certificate}

The Swine Production Management Certificate program prompts students to customize their certificate with specific scientific disciplines and production practices. This 24-credit certificate provides the appropriate background and context for students to develop their swine production and management expertise.

The certificate requirements are organized to correspond with faculty and employer-defined needs for a successful transition from ISU student to swine industry

Copyright (C) 2021 by the Authors. This is an open access article published under the CC BY-NC license (https://creativecommons.org/licenses/by-nc/4.0/), which allows for non-commercial reuse with proper attribution. 
professional. Successful completion of the certificate requires a minimum of 18 credits at the 300 (junior) or 400 (senior) level. The program integrates swine production principles with foundation disciplines in animal science. All courses in the certificate are available, and full descriptions are available in the Iowa State University Catalog (https://catalog.iastate.edu).

The certificate requires completion of courses within the following categories: Foundation ( 3 credits), Fundamental Disciplines ( 9 credits), Expertise Expansion (3 credits from a menu), Management (3 credits from a menu), and Swine Production Emphasis (6 credits). Per ISU policy, nine credits will be unique to the certificate and will not be applied to a major, minor, or another certificate.

\section{Availability of the Swine Production Management Certificate}

The Swine Science Certificate has been approved by the Department of Animal Science Curriculum Committee, the College of Agriculture and Life Sciences College Curriculum committee, and the Faculty Senate. Therefore, the Swine Science Certificate will be available to ISU undergraduate students beginning in the fall of 2021.

\section{SWine Production Management \\ Certificate (24 CREDits)}

\begin{tabular}{|c|c|c|}
\hline \multicolumn{2}{|c|}{$\begin{array}{l}\text { Foundation Course } \\
\text { (3 credits) }\end{array}$} & \multirow{2}{*}{$\begin{array}{r}\text { Credits } \\
3\end{array}$} \\
\hline ANS 225 & Swine Science & \\
\hline \multicolumn{3}{|c|}{ Fundamental Disciplines (9 credits) } \\
\hline AN S 320 & Animal Feeds and Feeding & 3 \\
\hline AN S 331 & $\begin{array}{l}\text { Domestic Animal } \\
\text { Reproduction }\end{array}$ & 3 \\
\hline AN S 352 & $\begin{array}{l}\text { Genetic Improvement of } \\
\text { Domestic Animals }\end{array}$ & 3 \\
\hline \multicolumn{3}{|c|}{ Expertise Expansion (3 Credits) } \\
\hline AN S 333 & $\begin{array}{l}\text { Embryo Transfer and } \\
\text { Related Technologies }\end{array}$ & 3 \\
\hline AN S 336 & $\begin{array}{l}\text { Domestic Animal Behavior } \\
\text { and Well-Being }\end{array}$ & 3 \\
\hline AN S 345 & $\begin{array}{l}\text { Growth and Development of } \\
\text { Domestic Animals }\end{array}$ & 3 \\
\hline AN S 360 & Fresh Meats & 3 \\
\hline AN S 380C & $\begin{array}{l}\text { Employee Management for } \\
\text { the Swine Industry }\end{array}$ & 1 \\
\hline AN S 380D & Farrowing Management & 1 \\
\hline AN S 380E & $\begin{array}{l}\text { Swine Feed Mill } \\
\text { Management }\end{array}$ & 1 \\
\hline AN S 380F & $\begin{array}{l}\text { Marketing and Risk } \\
\text { Management in the Swine } \\
\text { Industry }\end{array}$ & 1 \\
\hline AN S 380G & $\begin{array}{l}\text { Swine Nursery and Finishing } \\
\text { Management }\end{array}$ & 1 \\
\hline AN S 382 & $\begin{array}{l}\text { Swine Environment } \\
\text { Management }\end{array}$ & 1 \\
\hline AN S 383 & $\begin{array}{l}\text { Swine Manure and Nutrient } \\
\text { Management }\end{array}$ & 1 \\
\hline AN S 384 & $\begin{array}{l}\text { Swine Health and } \\
\text { Biosecurity }\end{array}$ & 1 \\
\hline TSM 327 & Animal Production Systems & 3 \\
\hline TSM 455 & $\begin{array}{l}\text { Feed Processing and } \\
\text { Technology }\end{array}$ & 3 \\
\hline TSM 457 & $\begin{array}{l}\text { Feed Safety, Ingredient } \\
\text { Quality, and Analytics }\end{array}$ & 3 \\
\hline VDPAM 487 & $\begin{array}{l}\text { Livestock Disease } \\
\text { Prevention }\end{array}$ & 3 \\
\hline \multicolumn{3}{|c|}{ Enterprise Management (3 credits) } \\
\hline AGEDS 451 & Agricultural Law & 3 \\
\hline ECON 230 & Farm Business Management & 3 \\
\hline ECON 235 & $\begin{array}{l}\text { Introduction to Agricultural } \\
\text { Markets }\end{array}$ & 3 \\
\hline ECON 332 & Cooperatives & 3 \\
\hline ECON 334 & $\begin{array}{l}\text { Entrepreneurship in } \\
\text { Agriculture }\end{array}$ & 3 \\
\hline \multicolumn{3}{|c|}{ Swine Production Emphasis (6 credits) } \\
\hline AN S 425 & Swine Systems Management & 3 \\
\hline AN S 399 & Swine Internship Experience & 3 \\
\hline
\end{tabular}

